\title{
Oak Ridge Reservation Annual Site Environmental Report Summary for 1993
}

Date Published: November 1994

Prepared by

Environmental, Safety, and Health Compliance and

Environmental Management staffs of the

Oak Ridge Y-12 Plant, Oak Ridge National Laboratory, and Oak Ridge K-25 Site managed by

MARTIN MARIETTA ENERGY SYSTEMS, INC.

P.O. Box 2008

Oak Ridge, Tennessee 37831-6285 for the

U.S. DEPARTMENT OF ENERGY under Contract No. DE-AC05-84OR21400 


\section{DISCLAIMER}

This report was prepared as an account of work sponsored by an agency of the United States Government. Neither the United States Government nor any agency thereof, nor any of their employees, makes any warranty, express or implied, or assumes any legal liability or responsibility for the accuracy, completeness, or usefulness of any information, apparatus, product, or process disclosed, or represents that its use would not infringe privately owned rights. Reference herein to any specific commercial product, process, or service by trade name, trademark, manufacturer, or otherwise does not necessarily constitute or imply its endorsement, recommendation, or favoring by the United States Government or any agency thereof. The views and opinions of authors expressed herein do not necessarily state or reflect those of the United States Government or any agency thereof. 


\section{DISCLAIMER}

Portions of this document may be illegible in electronic image products. Images are produced from the best available original document. 


\section{Contents}

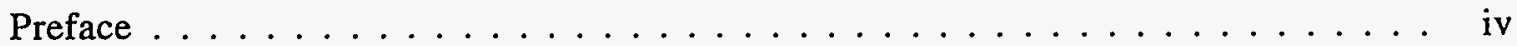

About the Oak Ridge Reservation . . . . . . . . . . . . . . . 1

Environmental Awareness Programs . . . . . . . . . . . . . . 2

Environmental Compliance $\ldots \ldots \ldots \ldots \ldots \ldots$

Environmental Monitoring and Restoration $\ldots \ldots \ldots \ldots$

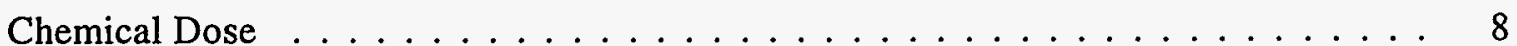

Nonradiological Monitoring and Surveillance . . . . . . . . . . . . . 11

Radiological Monitoring and Surveillance . . . . . . . . . . . . . . . 13

Perspective on Radiation and Dose . . . . . . . . . . . . . . 21 


\section{Preface}

The U.S. Department of Energy requires annual site environmental reports from facilities that operate under its auspices. To fulfill that requirement, such an annual report is published for the Oak Ridge Reservation, which comprises three major sites, each of which has unique monitoring requirements in addition to many shared obligations. As a result, the report is complex and highly detailed.

Annual site environmental reports are public documents that are read by government regulators, scientists, engineers, business people, special interest groups, and members of the public at large. For that reason, the reports need to be accessible to a variety of audiences in addition to being accurate and complete. This pamphlet summarizes environmental activities on the reservation, which for some readers may be adequate; for those who seek more detail, it will lend coherence to their approach to the report itself.

The content of this summary was taken from Oak Ridge Reservation Annual Site Environmental Report for 1993. Results of the many environmental monitoring and surveillance activities are detailed in this report.

Copies of both this summary (document No. ES/ESH-49) and the detailed report (document No. ES/ESH-47) are available from ORNL Laboratory Records, P.O. Box 2008, Oak Ridge, TN 37831-6285. The authors encourage comments on both documents so that the needs of our readers can be better addressed. Please direct your comments to ASER Editor, P.O. Box 2008, Oak Ridge, TN 37831-6144. 


\section{ABOUT THE OAK RIDGE RESERVATION}

The Oak Ridge Reservation (ORR) is a 34,700-acre federally owned facility managed by the U.S. Department of Energy (DOE). The three major sites on the reservation-the Oak Ridge Y-12 Plant, the Oak Ridge National Laboratory (ORNL), and the Oak Ridge K-25 Site (Figure 1)-were established in the early 1940s as part of the Manhattan Project, the secret undertaking to develop and produce the nation's first atomic bombs. Martin Marietta Energy Systems, Inc. (Energy Systems), is the prime contractor for the three facilities on the ORR.

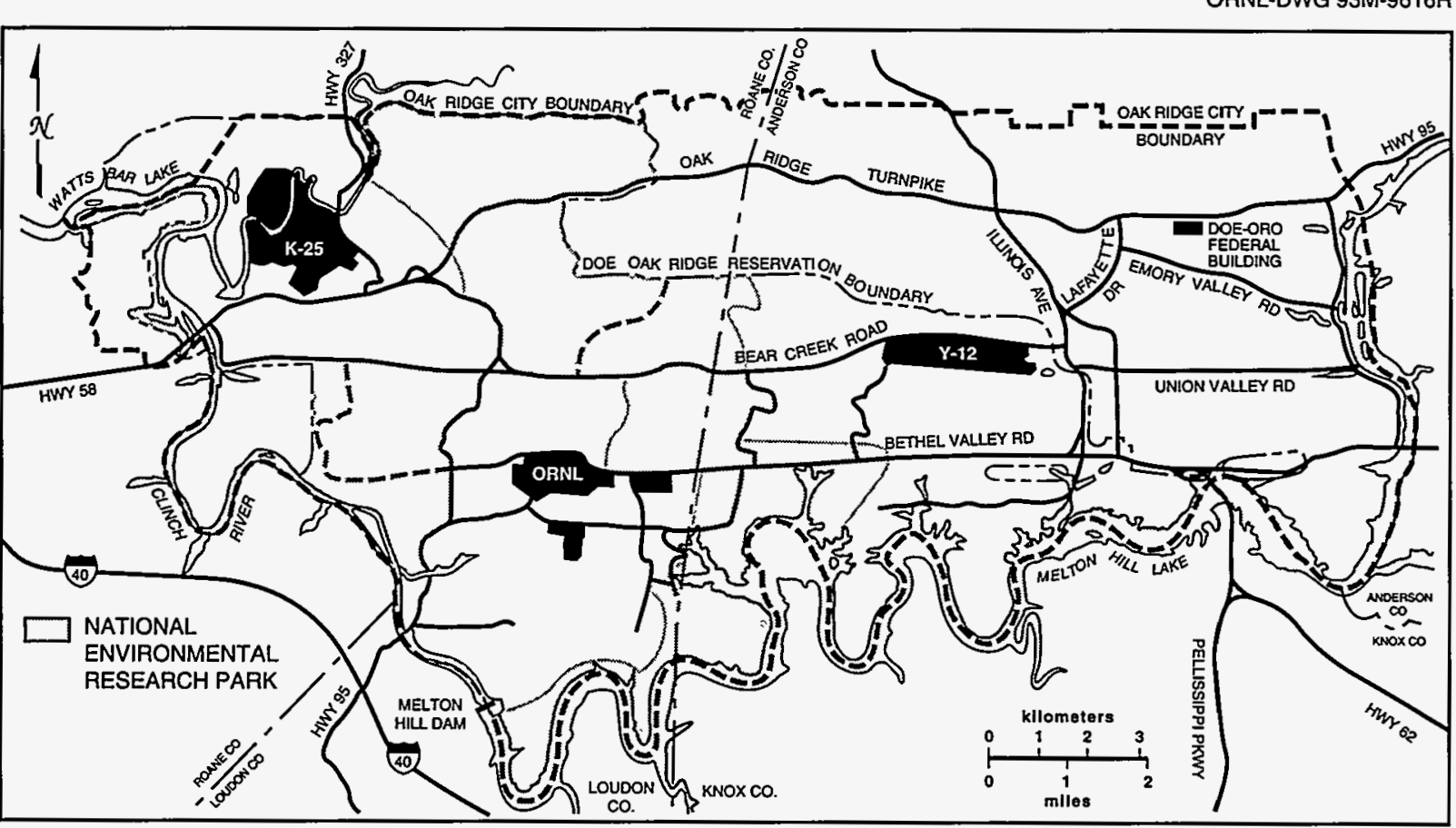

Figure 1. The Oak Ridge Reservation.

The reservation's role has evolved over the years and continues to change to meet the changing defense, energy, and environmental needs of the United States. Currently, the ORR facilities are involved in areas such as environmental technology development, materials research and development, technology transfer, and radioisotope production. The work carried out for the war effort and subsequent research, development, and production activities have produced hazardous wastes and continue to do so today. For that reason, documented environmental monitoring is required for these facilities.

The ORR borders the city of Oak Ridge, located in Anderson and Roane counties in east Tennessee about 25 miles west of Knoxville (Figure 2). Oak Ridge lies in a valley between the Cumberland and southern Appalachian mountain ranges and is bordered on two sides by the Clinch River. The Cumberland Mountains are about 10 miles to the northwest; the Great Smoky Mountains National Park is about 32 miles to the southeast. The residential section of Oak Ridge forms the northern boundary of the reservation. The Tennessee Valley Authority's Melton Hill and Watts Bar reservoirs on the Clinch and Tennessee rivers form the eastern, southern, and western boundaries. 
ORNL-DWG 93M-6313R

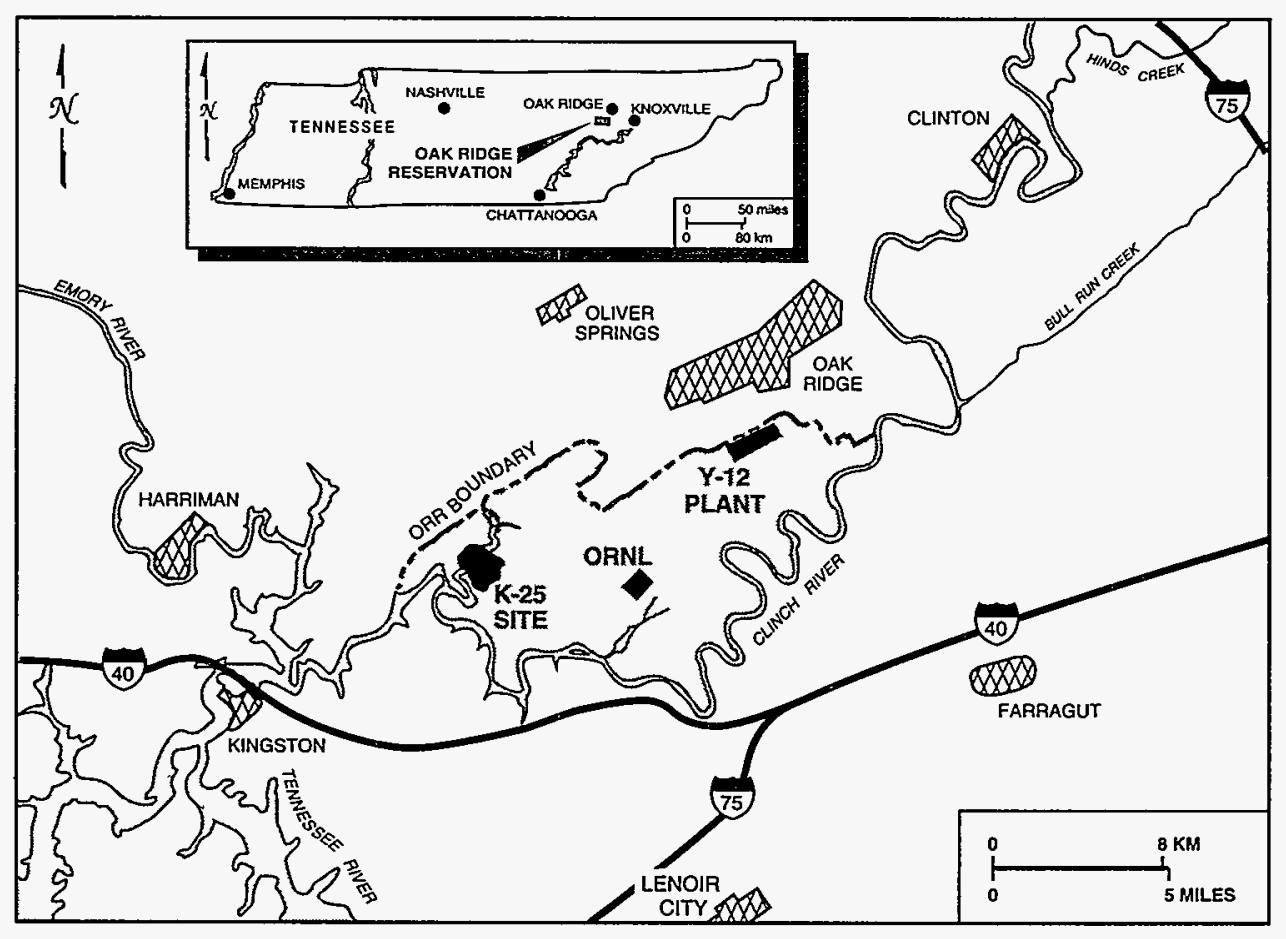

Figure 2. Location of the city of Oak Ridge.

\section{ENVIRONMENTAL AWARENESS PROGRAMS}

The purpose of the environmental awareness programs at the ORR is to protect and restore the local environment and to inform, educate, and involve the public.

\section{Pollution Prevention and Waste Minimization}

The philosophy of pollution prevention and waste minimization has become an integral part of the ORR environmental program. It encompasses a wide variety of activities, including waste minimization and reduction, toxics-use reduction, procurement of environmentally friendly materials, and resource and energy conservation.

Awareness programs are conducted to help ORR employees understand pollution prevention and waste minimization concepts and to encourage them to contribute ideas on how to minimize waste and pollutants and increase the efficiency of processes. For example, the K-25 Site hosted a pollution prevention month, of which one activity, War on Paper, collected about 32 tons of paper for recycling (the equivalent of 541 trees). The Y-12 Plant sponsored "Save Our Plan(e)t," a campaign to encourage reduction, reuse, and recycling at home and at work. For the last two years, Energy Systems has sponsored a cleanup of the shoreline along Melton Hill Lake as part of Earth Day celebrations.

\section{Centers for Environmental Technology and Waste Management}

In May 1993, the K-25 Site was dedicated as the home of DOE's Center for Environmental Technology and the Center for Waste Management. The centers will foster partnerships between technology users and technology suppliers from governmental, academic, scientific, and private sectors to use innovative, cost-effective technologies to 
decrease the cost of environmental restoration and waste management. The centers will accelerate development, demonstration, and commercialization of improved environmental technologies for DOE, other federal agencies, and the commercial sector.

\section{Mixed-Waste Management}

About 136 million pounds of mixed waste (waste containing both radioactive and hazardous-chemical components) is currently stored on the reservation, and about 4 million pounds is generated annually, primarily from cleanup and decontamination and decommissioning efforts. The proposed treatment of these wastes under the Federal Facilities Compliance Act will be costly, and waste management decisions facing the ORR and the state may affect local communities. Public participation in the early stages of decision-making can help identify issues and focus the planning efforts.

The Federal Facilities Compliance Act, enacted in 1992, is intended to bring federal facilities into full compliance with the Resource Conservation and Recovery Act (RCRA). Key aspects of the act relating to mixed-waste management include the following:

- A waiver of the government's sovereign immunity allows fines and penalties to be imposed for RCRA violations.

- Federal agencies are required to work with EPA and the states to provide comprehensive data on mixed-waste inventories, treatment capacity, and treatment plans.

- Members of the public are to be informed about waste treatment options and are encouraged to participate in decisions affecting federal facilities.

The DOE Oak Ridge Operations Office (DOE-ORO) has the lead role in working with the regulatory agencies and the local citizens to develop a site treatment plan for the ORR. A conceptual site treatment plan, submitted in 1993 to the state of Tennessee, must be finalized 1995. Once it is approved, the state will enter into a consent order that will require DOE to comply with the plan.

Existing mixed-waste treatment facilities on the ORR will be used to treat mixed waste. These include the following:

- the Y-12 Plant Central Pollution Control Facility, to treat aqueous mixed wastes;

- the K-25 Site Toxic Substances Control Act (TSCA) Incinerator, to treat organic liquid mixed-waste streams and combustible solids; and

- the K-25 Site Central Neutralization Facility, to treat aqueous mixed wastes.

In addition, a number of technologies currently under development may soon be available to provide a more efficient means for treating mixed wastes generated on the ORR.

\section{Community Participation}

Community awareness and involvement are vital to the success of DOE's environmental restoration and waste management programs. Federal law requires public comment on proposed cleanup plans, and such public input has a direct bearing on decisions that are made. Citizens can participate in a number of ways:

- The DOE Stakeholders Group gives area citizens an opportunity to meet with DOE officials to discuss environmental restoration and waste management activities.

- The East Fork Poplar Creek Citizens' Working Group provides the opportunity for two-way communication between the community and the team working to clean up the East Fork Poplar Creek floodplain. 
- The annual

EnvironMENTAL Fair enhances the educational experience of middle-school students by increasing their awareness of local and global environmental issues and encouraging them to pursue environmentally related careers (Figure 3).

- Environmental Update is a newsletter published to keep area residents informed of environmental restoration and waste management activities under way or under consideration on the ORR. The newsletter is inserted into area newspapers and is kept on file at the DOE Information Resource Center.

- The DOE Information Resource Center, located at 105 Broadway in Oak Ridge, houses the Administrative Record, a collection of files that contains all the information on which environmental cleanup decisions are based.

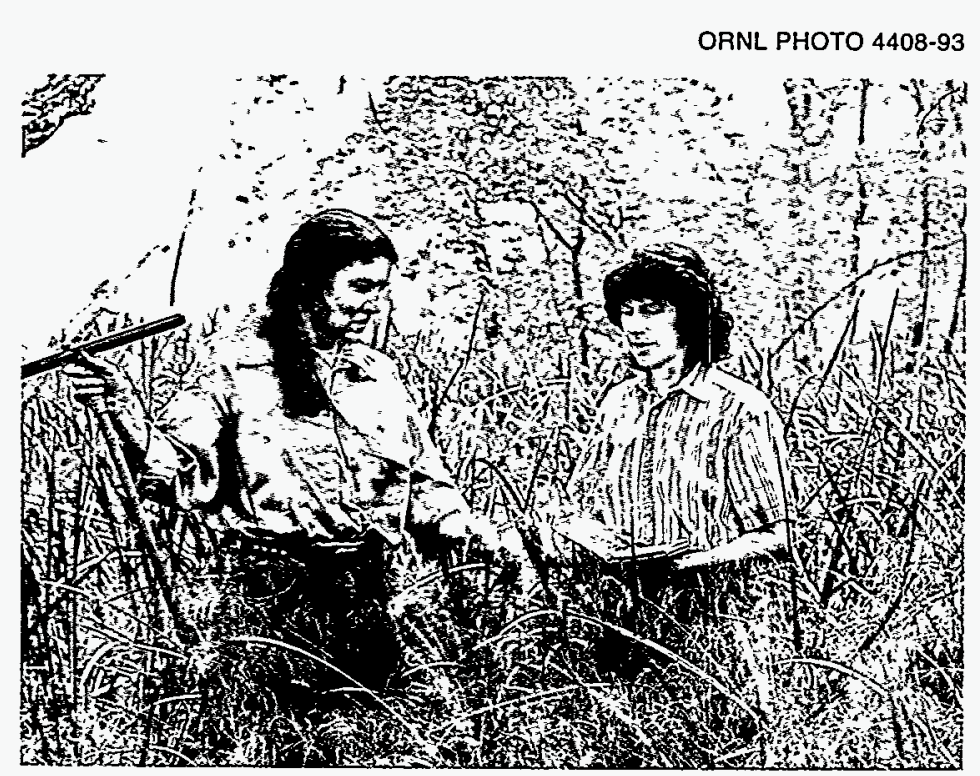

Figure 4. Biologists examine the soils and vegetation of a wetland on the reservation.

\section{Environmental Research}

\section{Oak Ridge Narional Environmental Research Park}

The 13,590-acre Oak Ridge National

Environmental Research Park was established in 1980 . The purpose of the park is to provide protected land areas for research and education in the environmental sciences and to demonstrate that energy technology development can be compatible with a quality environment (Figure 4). The park is an outdoor laboratory available for basic and applied research projects. A data base of wetland and plant information and a plant and animal reference collection are maintained for the reservation. In addition, the park serves as protection for special habitats, such as those with rare plants or animals. 


\section{Clinch River Environmental Studies Organization}

In 1988 , three local school districts (Anderson County, Clinton, and Oak Ridge) joined in a partnership to establish a field laboratory for environmental science education. The Clinch River Environmental Studies Organization (CRESO), sponsored by DOE, manages a 130-acre site along the Clinch River in Anderson County. The site, formerly a landfill, was donated by the Anderson County Commission for long-term use as an environmental sanctuary. Teams of students and faculty study plant, animal, and aquatic life at the site (Figure 5). The teams prepare research reports

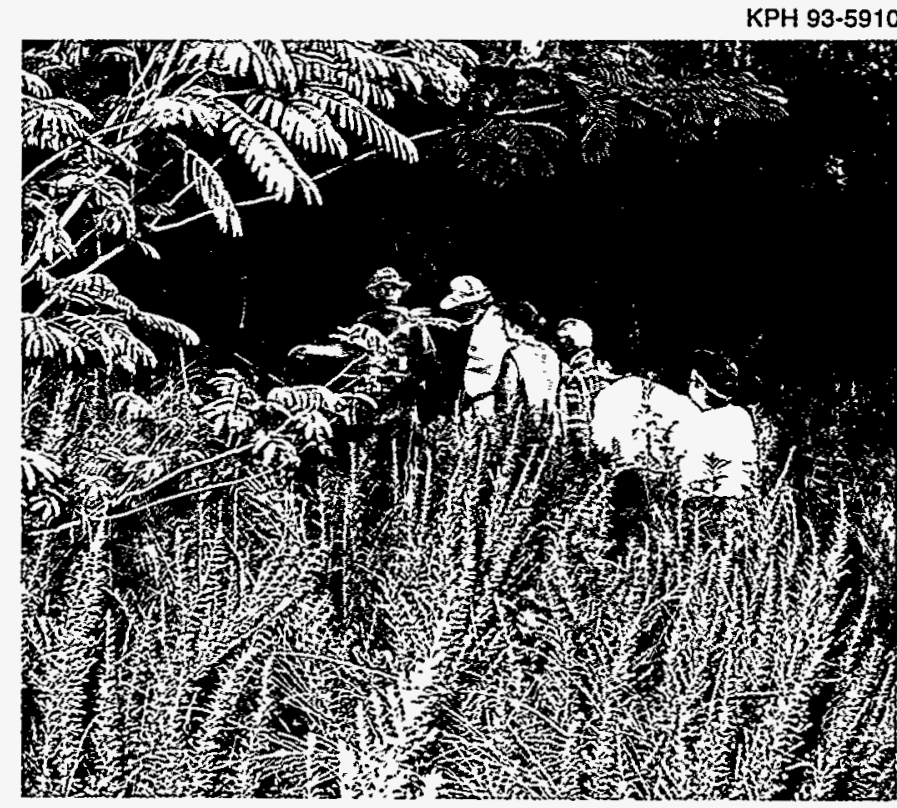

Figure 5. A group of teachers are shown the receiver and directional antenna used to track king snakes that have been implanted with transmitters. and present their research results at an annual symposium. In addition, researchers have shared their experiences with students visiting from local schools and groups from other states and countries. Hundreds of students and teachers have been involved in CRESO, either as members of research teams or as volunteers.

\section{ENVIRONMENTAL COMPLIANCE}

Compliance with environmental regulations and DOE orders related to environmental protection is an important part of operations on the ORR. The U.S. Environmental Protection Agency (EPA) (both headquarters and the Region IV office in Atlanta) and the Tennessee Department of Environment and Conservation (TDEC) are the principal regulatory agencies. These agencies issue permits, review compliance reports, participate in joint monitoring programs, inspect facilities and operations, and oversee compliance with applicable regulations. ORR facilities must comply with numerous federal and state laws, a few of which follow.

\author{
Clean Air Act \\ Clean Water Act \\ Comprehensive Environmental Response, \\ Compensation, and Liability Act \\ DOE/Tennessee Agreement-In-Principle \\ Endangered Species Act
}

\author{
Farmland Protection Policy Act \\ National Environmental Policy Act \\ National Historic Preservation Act \\ Resource Conservation and Recovery Act \\ Safe Drinking Water Act \\ Toxic Substances Control Act
}

The Resource Conservation and Recovery Act (RCRA) and the Comprehensive Environmental Response, Compensation, and Liability Act (CERCLA) both contain similar four-step corrective action processes. For that reason, DOE, EPA, and TDEC negotiated an agreement in 1992 to integrate RCRA and CERCLA. The agreement was negotiated to ensure that the environmental impacts associated with past and current activities on the 
ORR are thoroughly investigated and that appropriate remedial actions or corrective measures are taken as necessary to protect human health and the environment.

To ensure that compliance with environmental laws is maintained, numerous oversight activities are performed by internal and external organizations. These activities include audits, appraisals, inspections, and surveillances. The basic goal of these oversight activities is to evaluate whether the environmental laws are being met and to improve environmental operations. During 1993, 42 audits, appraisals, inspections, or surveillances of environmental programs were conducted. This number does not include those of internal Energy Systems and Martin Marietta Corporation teams.

\section{ENVIRONMENTAL MONITORING AND RESTORATION}

\section{Environmental Monitoring}

The operation of most industrial facilities involves processing and handling of materials that if released to the environment could cause harm. As a result of routine operations at the ORR, radioactive contaminants and nonradioactive contaminants, such as chemicals and metals, are released to the environment. The ORR has an extensive environmental monitoring program to ensure that these releases do not exceed allowable levels established by federal and state regulatory agencies.

The ORR environmental monitoring program has two components-effluent monitoring and environmental surveillance, both of which are intended to demonstrate that ORR operations comply with DOE and other applicable federal, state, and local standards and requirements. Data from this program are used to evaluate the impacts (if any) of ORR operations on public health or the environment. The reservation is routinely monitored for radiation, radioactive materials, and chemical substances. This information is then used to document compliance with appropriate standards, identify trends, provide information to the public, and contribute to general environmental knowledge. The environmental monitoring program assists in (1) fulfilling DOE's policy of protecting the public, employees, and the environment from harm that could be caused by its activities and (2) reducing negative environmental impacts to the greatest degree practical.

\section{Monitoring versus surveillance \\ Per DOE Order 5400.5, Radiation Protection of the Public and the Environment:}

Effluent monitoring is the collection and analysis of samples or measurements of liquid and gaseous effluents for purposes of characterizing and quantifying contaminants, assessing radiation exposure to members of the public, and demonstrating compliance with applicable standards.

Environmental surveillance is the collection and analysis of samples of air, water, soil, foodstuffs, biota, and other media from DOE sites and their environs and the measurement of external radiation for purposes of demonstrating compliance with applicable standards, assessing radiation exposures to members of the public, and assessing effects, if any, on the local environment.

Monitoring occurs at the point of discharge, such as an air stack or drainage pipe, whereas surveillance involves looking for contaminants already present in the environment. 


\section{Environmental Restoration}

Environmental restoration is the process of cleaning up inactive waste sites and facilities to ensure that risks to human health and the environment are either eliminated or reduced to safe levels. This task may be accomplished by removing, stabilizing, or treating hazardous substances.

The federal law that addresses the restoration of inactive waste sites is CERCLA. This legislation includes identification of waste sites with the most urgent need for cleanup because of the increased risk to public health or the environment. These sites are put on EPA's National Priorities List. In December 1989, the ORR was added to this list.

The following are highlights of environmental restoration activities under way during 1993.

- Kerr Hollow Quarry. The 55-ft-deep quarry had been used from 1951 to 1988 as a treatment site for water-reactive and shock-sensitive materials. Waste containers were rolled into the quarry from a chute, then shot by security guards to allow water to enter the containers and react with the waste to render it nonhazardous. More than 19,000 items were removed from the quarry during the cleanup, completed in December 1993 (Figure 6).

- Cesium Plots. In the late 1960s, four plots of ground on the ORR alongside the Clinch River were treated with cesium to research the effects of nuclear fallout on the environment. Although the plots do not pose a long-term problem, DOE, EPA, and the TDEC have agreed to an interim remedial action to reduce the level of contamination. This project was completed in May 1994.

- Atomic City Auto Parts. Atomic City Auto Parts is an active salvage yard operation in the city of Oak Ridge once used for salvaging materials and equipment purchased from DOE's Oak Ridge facilities and other sources. In December 1992, DOE agreed to take the lead in cleaning up the facility, which was contaminated by polychlorinated biphenyls (PCBs), radiological contaminants, and heavy metals. Cleanup was completed in January 1994.

- RCRA Closure of Y-12 Plant Walk-in Pits. This site, one of the last RCRA units in the Y-12 Plant's Bear Creek Burial Grounds to undergo corrective action, was first used in the 1960s for burial of contaminated materials and shock-sensitive chemicals. Because of its location,

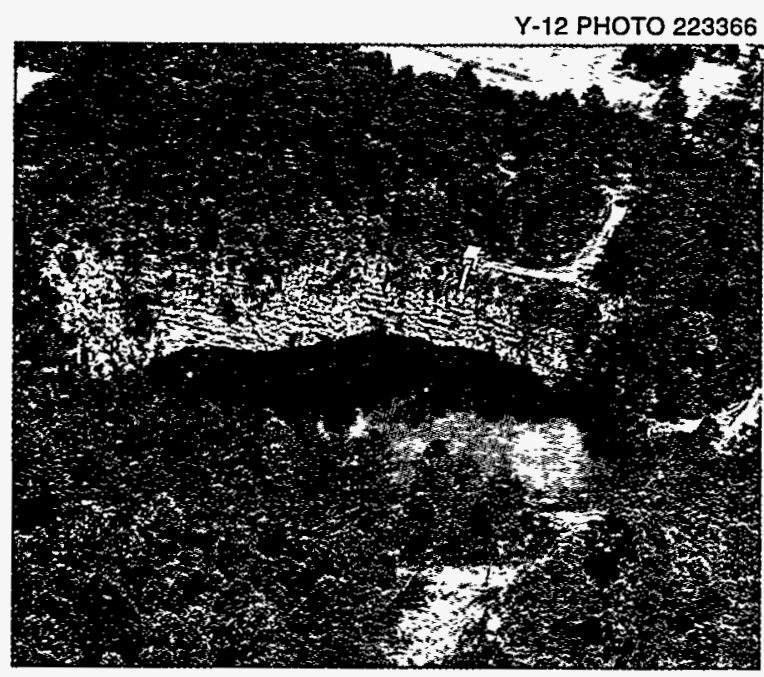

(a)

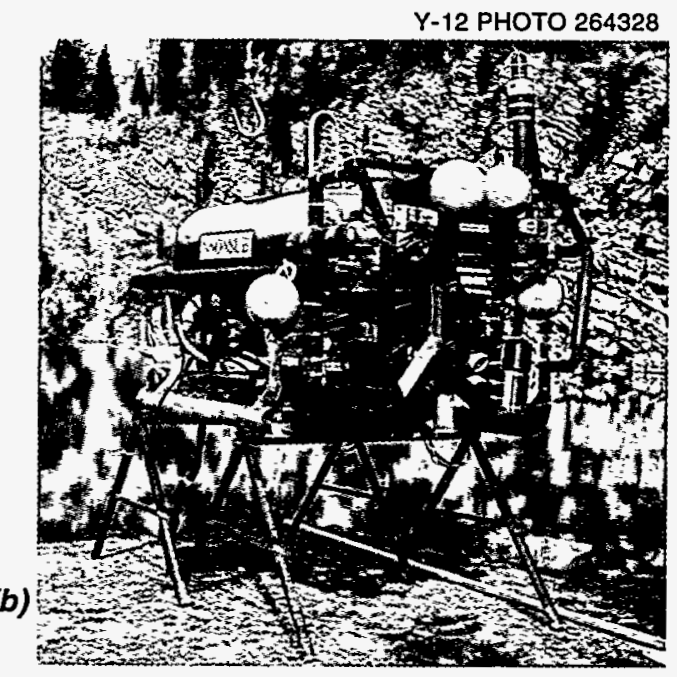

Figure 6. More than 19,000 items were removed from Kerr Hollow Quarry (a), a former treatment site for water-reactive and shock-sensitive materials. Because of the underwater nature of the work, special equipment, such as a remotely operated vehicle $(b)$, was used to complete the cleanup. 
another former waste

disposal area, Bear Creek

Burial Ground B, was also capped as part of the Walk-in

Pits closure. This project was completed in May 1994

(Figure 7).

- East Fork Poplar Creek. In 1983, DOE announced that the floodplain of East Fork Poplar Creek, which begins inside the Y-12 Plant boundary and runs west through the city of Oak Ridge, had been contaminated by off-site releases from the Y-12 Plant.

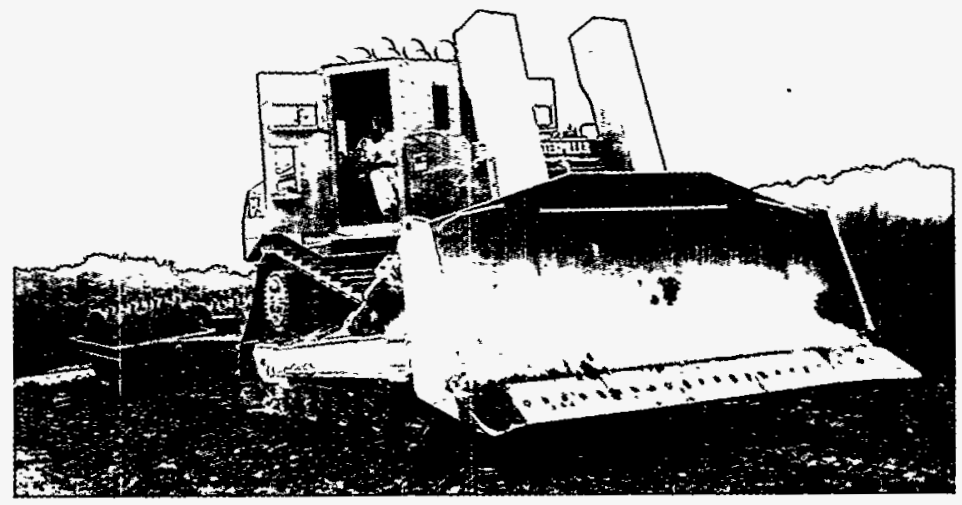

Figure 7. Because of the explosive nature of some of the wastes in the Y-12 Plant Walk-in Pits, an armor-plated bulldozer was used during the RCRA closure of the pits.

Mercury, used primarily in

isotope separation processes at the plant, was identified as the primary contaminant. Other heavy metals, radionuclides, and organic compounds are also present in small amounts. Preliminary studies indicate that the contamination in the floodplain soils poses no immediate threat to public health. In late summer or early fall 1994, the public will have an opportunity to comment on the remediation plan proposed by DOE and the preferred alternative.

- Clinch River/Watts Bar Reservoir. Past operations and disposal practices on the ORR have led to low-level contamination in the Clinch River and Watts Bar Reservoir. Peak releases of most contaminants occurred 30 to 40 years ago and included radioactive elements, heavy metals, and organic compounds. Studies have indicated that the levels of contamination pose no imminent risk to human health or the environment. In January 1994, EPA granted formal approval to split the study area into two operable units, the Lower Watts Bar Reservoir study area and the Clinch River study area. A combined remedial investigation/feasibility study for the Lower Watts Bar Reservoir study area should be completed in November 1994. The Phase 2 investigation of the Clinch River study area began in summer 1993.

- K-25 Site SW31 Perennial Spring. The SW31 Perennial Spring receives groundwater from burial grounds where a variety of wastes were buried during the 1970 s. The primary contaminants of concern are volatile organics. During 1993, a capture system was installed to contain the water for shipment to the Y-12 Plant for treatment. Design is proceeding for upgrading existing K-25 Site facilities to be able to treat the water. Completion of the upgrade is scheduled for late 1995 .

\section{CHEMICAL DOSE}

\section{Perspective on Chemicals}

The lives of modern humans have been greatly improved by the development of chemicals such as pharmaceuticals, building materials, housewares, pesticides, and industrial chemicals. Through the use of chemicals we can increase food production, cure diseases, build more efficient houses, and send people to the moon. At the same time we must be cautious to ensure that our own existence is not endangered by widespread, uncontrolled, overuse of chemicals. 
All humans are exposed to chemicals in their normal daily routine. Some potentially hazardous chemicals do exist in the natural environment. In many areas of the country, soils contain naturally elevated concentrations of metals such as selenium, arsenic, or molybdenum, which may be hazardous to humans or animals. However, exposures to many more hazardous chemicals result from the direct or indirect actions of humans. Building materials used in the construction of houses may contain chemicals such as formaldehyde (in some insulation materials), asbestos (formerly used in insulation and ceiling tiles), and lead (formerly used in paints). Some chemicals are present as a result of application of pesticides and fertilizers to soil. Other chemicals may have been transported long distances through the atmosphere from industrial sources before being deposited on soil or water.

\section{Pathways of Chemicals from the ORR to the Public}

Pathways refer to the route or way in which a person can come in contact with a chemical substance. Chemicals released to the air may remain suspended for long periods of time, or they may be deposited on plants, soil, and water. Chemicals may also be released as liquid wastes called effluents, which can enter streams and rivers.

People are exposed to chemicals by inhalation (breathing air), ingestion (eating exposed plants and animals or drinking water), or by direct contact (touching the soil or swimming in water). For example, fish in a river that receives effluents may take up some of the chemicals present. People eating the fish would then be exposed to the chemical. Less likely would be exposure by drinking from the stream or river.

The public is not normally exposed to chemicals on the ORR because access to the reservation is limited. However, chemicals released as a result of ORR operations can move through the environment to off-site locations, possibly resulting in exposure to the public.

\section{Measuring Chemicals}

Environmental samples are collected in areas surrounding the ORR and are analyzed for the chemical constituents that are most likely to be released from the ORR. Samples of liquid effluents are also collected. With modern analytical techniques, very small quantities of chemicals can be detected and measured in samples. However, some chemicals are present in such small amounts that they cannot be measured. Many of the sampling data for individual chemicals on the ORR are reported as "less-than" values, indicating that concentrations are below the limit of detection of the instruments used. These data are used in the analysis only if one or more samples have values above the detection limits.

\section{Exposure Assessment}

To assess exposure on the ORR, it is assumed that people are exposed to statistically significant concentrations of contaminants. In addition, it is assumed that people living beyond the ORR boundary drink 2 liters of water per day ( 730 liters per year) directly from the river and eat 58 grams of fish per day (21.2 kilograms per year) from the river. These assumptions are conservative but are used to ensure that no one is receiving a high dose from ORR effluents. Thus, estimated oral daily intakes or estimated doses to the public can be calculated by multiplying measured concentrations in water by 2 liters or multiplying measured concentrations in fish by 58 grams. 


\section{Toxicišy}

Toxicity refers to an adverse effect of a chemical on human health. Not all chemicals are toxic. Every day we ingest chemicals in the form of food, water, and sometimes medications. Even those chemicals that are usually considered toxic are usually nontoxic or harmless below a certain concentration. Concentration limits or advisories are set by government agencies for some chemicals that are known or thought to have an adverse effect on human health. These concentration limits can be used to calculate a chemical dose that would not harm even individuals who are particularly sensitive to the chemical.

Chemicals have varying types of effects. Generally, when considering human health, chemicals are divided into two broad categories: chemicals that cause health effects but do not cause cancer (noncarcinogens) and chemicals that cause cancer (carcinogens). The potential health effects of noncarcinogens range from irritation to life-shortening. Carcinogens cause or increase the incidence of cancers.

\section{Dose Assessment}

For chemicals, dose to humans is measured in terms of milligrams per kilogram per day ( $\mathrm{mg} \mathrm{kg}^{-1} \mathrm{day}^{-1}$ ). In this case, the "kilogram" refers to the body weight of an adult individual. When calculating a chemical dose, the length of time an individual is exposed to a certain concentration is important. To assess off-site doses, it is assumed that the exposure occurs over a lifetime, which is defined as 70 years. Such exposures are called chronic in contrast to short-term exposures, which are called acute.

\section{Waterborne Chemicals}

In previous annual environmental reports, the "calculated daily intakes," based on chemical concentrations in water or fish, were divided by the "acceptable daily intake," which is based on a reference dose (RfD). Current risk assessment methodologies use the term "hazard quotient" (HQ) to evaluate noncarcinogenic health effects. Therefore, in this environmental report the HQ methodology is used. Intakes, calculated in mg kg $\mathrm{day}^{-1}$ in the HQ methodology, are expressed in terms of dose. For carcinogens, the estimated dose (I) from ingestion of water or fish is divided by the chronic daily intake (CDI), which corresponds to a one-in-ten-thousand lifetime risk of developing cancer.

\section{Drinking Water}

With exceptions of aluminum, iron, and arsenic, the HQ values were less than 1 . The elevated iron and arsenic were found at CRK 84, which is above all DOE inputs. Estimation of HQs for arsenic at other water-sampling locations along the Clinch River (both above and below the ORR) resulted in HQs greater than 1. For aluminum, HQs greater than 1 were found at all locations both up and down stream of the ORR with the exception of CRK 58. The high concentration of aluminum at all locations may be a reflection of the turbidity and suspended solids in some of the samples. Furthermore, the criteria for concentration levels that apply to aluminum are not health-based values.

\section{Fish Consumption}

Chemicals in water can be accumulated by aquatic organisms that may be eaten by humans. Bluegill (sunfish) and catfish (at two locations) collected from the Clinch River and Poplar Creek were analyzed for a number of metals, pesticides, and PCBs. Chemicals 
with HQs greater than 1 were arsenic, mercury, and lead. Elevated levels of these contaminants were not observed in fish upstream of the ORR; however, HQs greater than 1 were observed for arsenic and lead in drinking water locations both above and downstream of the ORR. For carcinogens, I/CDI ratios greater than 1 indicate a risk greater than $10^{-5}$. Chemicals that had I/CDIs greater than one were 4,4'-DDE, alpha chlordane, and PCBs (Aroclor 1254 and 1260). The tissue concentrations of 4,4'-DDE and PCBs (Aroclor 1254 and 1260) were estimated at or below the analytical detection limit. Therefore, because of analytical detection limitations, the actual fish-tissue concentrations are unknown.

\section{NONRADIOLOGICAL MONITORING AND SURVEILLANCE}

The nonradiological monitoring program is designed to ensure that airborne and liquid releases are safe and within regulatory limits. Based on regulatory guides, the program focuses on monitoring of airborne and liquid releases (effluent monitoring) and surveillance of materials already in the environment, including air, surface water, groundwater, sediment (from streambeds), hay, and fish.

\section{Monitoring}

Nonradiological emissions of concern on the ORR include potentially harmful chemicals, pollutants, and ozone-depleting compounds. Facilities and operations that release such emissions include coal- and oil-fired boilers at the steam plants; maintenance facilities, such as paint shops; waste management facilities, such as the toxic substances incinerator at the K-25 Site; and production facilities at the Y-12 Plant. Emissions in 1993 were all within applicable limits, and air sampling at locations on and around the reservation indicated that concentrations of pollutants and chemicals were within applicable standards.

Similar to airborne emissions, liquid releases of concern include chemicals, metals, and pollutants. Monitoring of nonradiological liquid effluents is conducted at numerous outfalls (locations where liquids are discharged) that are regulated by the National Pollutant Discharge Elimination System. Nonconformances to permit requirements in 1993 were 14 at the Y-12 Plant, 22 at ORNL, and 10 at the K-25 site. Most of these nonconformances were minor; overall conformance for the ORR ranged from 83 to $100 \%$ for the year.

\section{Surface Water}

To assess the impact of DOE operations on the quality of local surface water, samples are collected and analyzed from 22 locations around the ORR. Sampling is also conducted at each of the three main sites. In most instances, analytical results for nonradiological parameters were well below applicable standards.

\section{Groundwater}

Groundwater aquifers are one of the primary pathways by which potentially hazardous substances can enter the environment. Aquifers are sections of underground material (such as earth, rock, or sand) that transmit water easily. Substances within the soil may be dissolved in rainwater, which moves them downward into the groundwater. The water then flows toward a discharge point. Because of the complexity of the ORR hydrogeology, groundwater flow and, therefore, contaminant transport is largely unpredictable on a local 


\section{Surface Water Sampling}

To assess the impact of DOE operations on the quality of local surface water, samples are collected and analyzed from 22 locations around the ORR. Sampling is also conducted at each of the three sites. In most instances, analytical results for radiological parameters were well below applicable standards and do not indicate that operations on the ORR are having any harmful effects on local surface waters.

\section{Groundwater Surveillance}

Most of the population in the Oak Ridge area does not rely on groundwater for potable water supplies. Suitable water is available, however, and local groundwater provides some domestic, municipal, farm, irrigation, and industrial uses. For that reason, the groundwater must be viewed as both a potential pathway for exposure to hazardous wastes and as a means for contaminant transport. Radiological groundwater monitoring is conducted for specific radionuclides as well as general levels of radioactivity.

\section{Soil and Sediment Sampling}

Soil is sampled to determine if airborne radionuclides are accumulating in the soil. Soil samples are taken annually at 9 locations on the reservation. Detected radionuclides and levels of radioactivity were similar to 1992 and were all within acceptable ranges.

Stream and lake sediments act as a record of some aspects of water quality by storing and concentrating certain contaminants. For this reason, sediment samples were collected from 16 locations on and around the reservation. Sediment sampling was conducted on the ORR for the first time in 1993; therefore, statistical evaluation of the results for each location could not be performed. In addition, there are no regulatory standards that apply to sediments. After two years of monitoring, the data will be reviewed and analyses will be dropped or added as appropriate.

scale. Stormflow and most groundwater discharge to the surface-water drainages on the ORR. For that reason, monitoring surface water quality is a good way to assess the extent to which groundwater on the ORR transports contaminants. The numerous wells on the ORR provide for surveillance of groundwater quality. Additional characterization is being conducted in the Environmental Restoration Program.

Plant perimeter groundwater monitoring stations are used to assess potential migration of contaminants beyond the boundary of the ORR. Groundwater (and surface water) data collected from these stations during 1993 indicate that only a few locations at the Y-12 Plant and ORNL show any evidence of contamination. At the Y-12 Plant, results from several recently completed wells and a group of off-site U.S. Geological Survey wells indicate that groundwater contaminated with volatile organic compounds is migrating eastward across Scarboro Road and into Union Valley. There are no users of groundwater in the affected area. Results from the off-site spring and residential well monitoring program indicate no evidence of contamination at these locations during 1993.

\section{Sediment}

Stream and lake sediments act as a record of some aspects of water quality by storing and concentrating certain contaminants. For this reason, sediment samples are collected annually from 16 locations on and around the reservation and are analyzed for metals, chlorinated pesticides, PCBs, and hazardous organic compounds. Sediment sampling was 
conducted on the ORR for the first time in 1993; therefore, statistical evaluation of the results for each location could not be performed. In addition, there are no regulatory standards that apply to sediments. After two years of monitoring, the data will be reviewed and analyses will be dropped or added as appropriate.

\section{Hay}

Hay is cut on the ORR and sold to area farmers for fodder. Six locations from which hay is cut have been identified as areas where airborne materials could be deposited from ORR sources. Hay samples were collected during May and June and analyzed for fluorides. Although standards for concentrations of fluorides in hay do not exist, analyses do not indicate that $\mathrm{DOE}$ operations are having any significant effects on local vegetation.

\section{Fish}

Members of the public potentially could be exposed to contaminants originating from DOE activities through consumption of fish caught in area waters. This exposure pathway is monitored by annually collecting and analyzing fish from 14 locations. Sampling sites are located upstream and downstream of DOE activities and at one off-site (background) location.

Sunfish are collected from each of the six river locations, filleted, and frozen. When enough fish have been collected (typically 150 to 200 per location), the samples are thawed and fillets from six of the largest samples are analyzed for selected metals, pesticides, and PCBs. To provide data from a second species, six to ten catfish are also collected at two locations, and a composite sample is analyzed for selected metals, pesticides, and PCBs. For all six locations, most parameters analyzed for in both sunfish and catfish were undetected. For PCBs, reported values for sunfish and catfish were below the federal Food and Drug Administration (FDA) tolerance of 2 parts per million; for mercury, all reported values were below the FDA action level of 1 part per million.

\section{RADIOLOGICAL MONITORING AND SURVEILLANCE}

Much of the environmental monitoring effort on the ORR is directed toward radioactive materials. The radiological monitoring and surveillance program is designed to determine any measurable effects DOE operations may have on the site, the surroundings, and the local population. Effluents (air and water) are monitored for a variety of radionuclides. Radiological sampling is conducted for air, surface water, groundwater, soil and sediment, food crops, fish, and wildlife. Direct radiation (external gamma radiation) is also measured. To understand how radiation is measured, it's necessary to understand what radiation is.

\section{Radiation}

All matter is made up of extremely small particles called atoms. Atoms are bundles of even smaller particles called protons, neutrons, and electrons. When an atom has the right combination of protons and neutrons, it is stable, or nonradioactive. Atoms that don't have the right combination break apart, or decay, in an attempt to become stable. When an unstable atom decays, it releases energy as particles and rays; this released energy is called radiation. 
Visible light, heat, radio waves, and alpha particles are examples of radiation. When people feel warmth from the sunlight, they are actually absorbing the radiant energy emitted by the sun. Electromagnetic radiation is radiation in the form of electromagnetic waves. Examples include gamma rays, ultraviolet light, and radio waves. Particulate radiation is radiation in the form of particles. Examples include alpha and beta particles. Radiation also is characterized as ionizing or nonionizing because of the way in which it interacts with matter.

Many materials are naturally radioactive. In fact, this naturally occurring radiation is the major source of radiation in the environment. Although people have little control over the amount of background radiation to which they are exposed, this exposure must be put into perspective. Background radiation remains relatively constant over time and is present in the environment today much as it was hundreds of years ago. Sources of background radiation include uranium in the earth, radon in the air, and potassium in food. Background radiation is categorized as cosmic, terrestrial, or internal, depending on its origin.

\section{Pathways of Radionuclides}

People can be exposed to radionuclides in the environment through a number of routes. Potential routes for internal or external exposure are referred to as pathways (Figure 8). For example, radionuclides in the air could fall on a pasture. The grass then could be eaten by cows, and the radionuclides deposited on the grass and ingested by the cows would show up in their milk. People drinking the milk would be exposed to this radiation. People also could simply inhale airborne radionuclides. Similarly, radionuclides in water could be ingested by fish, and people eating the fish would also ingest the radionuclides in the fish tissue. People swimming in the water could be exposed also.

\section{Measuring Radiation}

When we measure the amount of radiation in the environment, what is actually being measured is the rate of radioactive decay, or activity. The rate of decay varies widely among the various radioisotopes. For that reason, one gram of a radioactive substance may contain the same amount of activity as several tons of another material. This activity is expressed in a 


\section{Units of Radiation Measure}

To comply with DOE orders, the annual site environmental reports present results using the current system, followed by Système International (SI) units in parentheses. For example, the dose from a typical chest $X$ ray is 10 mrem $(0.10 \mathrm{mSv})$.

\begin{tabular}{lll} 
Current System & SI System & Conversion \\
\hline $\begin{array}{l}\text { Activity } \\
\text { curie (Ci) }\end{array}$ & becquerel (Bq) & $1 \mathrm{Ci}=3.7 \times 10^{10} \mathrm{~Bq}$ \\
$\begin{array}{l}\text { Absorbed dose } \\
\text { rad (radiation absorbed dose) }\end{array}$ & gray (Gy) & $1 \mathrm{rad}=0.01 \mathrm{~Gy}$ \\
$\begin{array}{l}\text { Dose equivalent } \\
\text { rem (roentgen equivalent man) }\end{array}$ & sievert (Sv) & $1 \mathrm{rem}=0.01 \mathrm{~Sv}$
\end{tabular}

\section{Converting Dose Equivalent}

Because a rem represents a fairly large dose of radiation, dose is best expressed as a millirem, or $1 / 1000$ of a rem. The same is true of sieverts. Dose is expressed in millisieverts (mSv). Because 1 mrem equals $0.01 \mathrm{mSv}$, converting from millirem to millisieverts is simply a matter of moving the decimal point two places to the left. For example, 267 mrem equals $2.67 \mathrm{mSv}$.

unit of measure known as a curie $(\mathrm{Ci})$. More specifically, one curie equals $3.7 \times 10^{10}$ $(37,000,000,000)$ atomic disintegrations per second (dps). In the international system of units, $1 \mathrm{dps}$ equals 1 becquerel $(\mathrm{Bq})$.

"Dose" is an estimate of the potential exposure of the human population to radiological components of the environment. Dose estimates are valuable indicators for assessing health risks and for confirming compliance with federal and state regulations. When doses are calculated, the maximum potential exposure is assumed, even though such exposure may be unlikely, which makes dose estimates very conservative.

Most doses associated with radionuclide releases to the environment are caused by interactions between human tissue and radiation emitted by the radionuclides. These interactions involve the transfer of energy from the radiation to tissue, a process that may damage the tissue. Radiation may come from radionuclides located outside the body (for example, in the air or the soil) or from radionuclides deposited inside the body (by inhalation, ingestion, and, in a few cases, absorption through the skin).

Exposures to radiation from nuclides located outside the body are called external exposures; exposures to radiation from nuclides deposited inside the body are called internal exposures. This distinction is important because external exposures occur only when a person is near or in the source of the radiation; internal exposures continue as long as the radionuclides remain inside the person. Also, external exposures may result in uniform irradiation of the entire body and all its components; internal exposures usually result in nonuniform irradiation of the body. (When taken into the body, most radionuclides deposit preferentially in specific organs or tissue and thus do not irradiate the body uniformly.) 


\section{Determining Dose}

The annual ORR radiological monitoring and surveillance program concludes with the calculation of dose. Determining dose is an involved process in which complex mathematical equations based on several factors, including type of radiation, rate of exposure, weather conditions, and typical diet, are used. Basically, radioactive decay, or activity, generates radiant energy. People absorb some of the energy to which they are exposed. The effect of this absorbed energy is responsible for an individual's dose. Whether radiation is natural or human-made, it has the same effect on people.

Many terms are used to report dose. The terms take several factors into account, including the amount of radiation absorbed, the organ absorbing the radiation, and the effect of the radiation over a 50-year period.

\section{Absorbed Dose}

When radiation interacts with matter, some of the energy is absorbed; the total amount of energy absorbed per unit mass is expressed in rad. The health effects of radiation are proportional to the absorbed dose. However, the proportion is different for different types of radiation. Consequently, limits for radiation exposure are normally expressed in relation to a standard radiation type (i.e., as dose equivalents).

\section{Dose Equivalent}

The potential biological damage caused by exposure to an absorption of radiation is expressed in rems. One rem of any type of radiation has the same total damaging effect. The dose equivalent is equal to the absorbed dose from each type of radiation multiplied by a "quality factor." The quality factors have been set by international organizations so that an equal number of rems means and equal effect on health regardless of the type of radiation involved. Because a rem represents a fairly large dose, the millirem, 1/1000 of a rem, is usually used to express the low levels of damage caused by radiation in the environment.

\section{Committed Dose Equivalent}

Normally, the largest part of a person's radiation dose is from radioactive material that has been swallowed or inhaled by that person. This material will continue to expose the person until it passes back out of the body, which may take longer than a single year. Therefore the committed dose equivalent, expressed in rem, is the total dose equivalent that a person is expected to receive over time from radioactive material that was swallowed or inhaled.

\section{Effective Dose Equivalent}

When radioactive materials are swallowed or inhaled, each organ can receive different, often very different, radiation exposures. Therefore, the effective dose equivalent (EDE) to an individual, expressed in rems, is an average of the committed dose equivalents to eleven major organs plus the dose equivalent caused by radiation from outside the body. EDE is used to express dose in terms of the potential health impact. Use of the EDE allows dose from different types of radiation and doses to different parts of the body to be expressed on the same basis. EDE is expressed in millirems. 


\section{Airborne Radionuclides}

Airborne emissions from the ORR were monitored for radionuclides, and all were within acceptable limits set by DOE and federal and state standards. The average concentrations of radionuclides at all monitoring locations were small percentages (all less than $1 \%$ ) of the allowable limits set by DOE. Measurements of radioactivity in the air on and around the ORR were also well within applicable standards and were not significantly affected by releases from the three sites.

Characterization of the radiological consequences of radionuclides released to the air from ORR operations during 1993 was accomplished by calculating, for each plant and for the entire ORR, EDEs to maximally exposed off-site individuals and to the entire population residing within 50 miles of the center of the ORR (Figures 9 and 10, respectively). Dose calculations were based on the assumption that each person remained at home (actually, outside the house), unprotected, during the entire year and obtained food according to conservative, well-defined patterns.

Figure 9. Individual EDEs to the maximally exposed individual from 1993 ORR airborne emissions, compared with the National Emission Standards for Hazardous Air Pollutants (NESHAP) standard. By comparison, the EDE from background radiation is $300 \mathrm{mrem}$.

Figure 10. Total ORR collective EDEs to the maximally exposed individual from 1993 ORR airborne emissions, compared with that of each site. By comparison, the total received from natural radiation within a 50 -mile radius of the ORR is 264,000 person-rem.

\section{Waterborne Radionuclides}

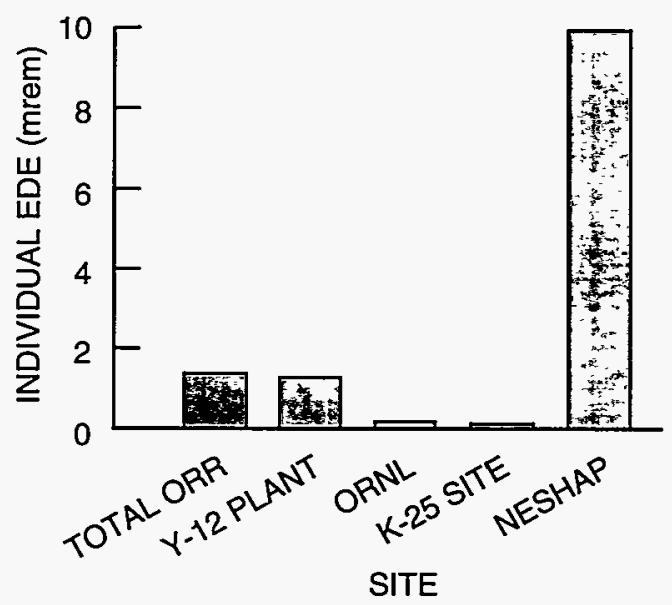

ORNL-DWG 94M-9708

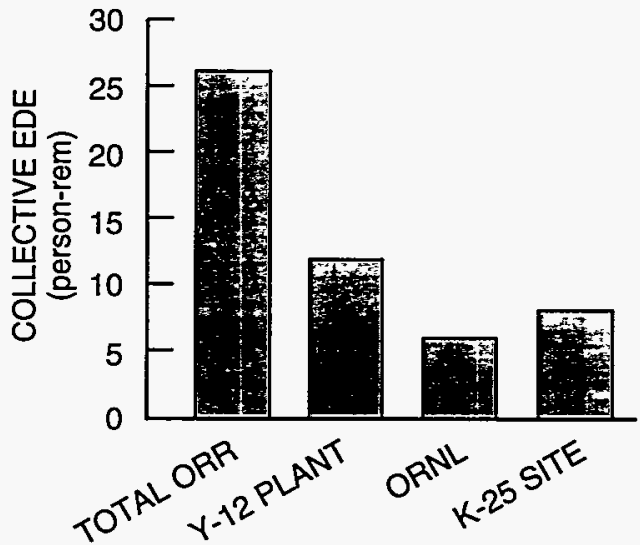

SITE

DOE sets limits for the maximum concentrations of radionuclides that are allowed in liquids discharged to the environment. For 1993, uranium was the major contributor of radioactivity; however, all concentrations were within allowable limits. Radionuclides 
discharged to surface waters from the ORR enter the Tennessee River system by way of the Clinch River and various feeder streams. The potential radiological impacts of these discharges were calculated for persons who drink water, eat fish, swim, boat, and use the shoreline at various locations along the Clinch and Tennessee rivers.

When all pathways are considered, the maximally exposed individual to waterborne radionuclide discharges could have received an EDE of about $0.4 \mathrm{mrem}: 0.2 \mathrm{mrem}$ from use of off-site waters plus 0.2 mrem from drinking K-25 Site water. The collective EDE to the 50-mile population was estimated to be about 2 person-rem. These are small percentages of individual and collective doses attributable to natural background radiation, $0.1 \%$ and $0.0008 \%$, respectively.

\section{Radionuclides in Other Environmental Media}

Milk

Ingestion is one of the pathways of exposure to radioactivity for humans. Radionuclides can be transferred from the environment to people via food chains such as the grass-cow-milk pathway. Milk is a potentially significant source to humans of some radionuclides deposited from airborne emissions because of the relatively large surface area that a cow can graze daily, the rapid transfer of milk from producer to consumer, and the importance of milk in the diet. The 1993 milk sampling program consisted of monthly samples collected from five locations in the vicinity of the ORR. Potential dose from milk ingestion was evaluated using concentrations of strontium and iodine measured in milk collected from nearby farms. An individual was assumed to drink 310 liters of milk containing the highest measured quantity of total strontium. Such an individual could have received an EDE of about 0.1 mrem. No iodine was detected in milk samples during 1993.

\section{Crops}

Another environmental pathway for ingestion, eating vegetables, was evaluated separately. Three types of vegetables were sampled: tomatoes, turnip greens, and turnips. These vegetable types were chosen as representative of fruit-bearing, leafy, and root vegetables. In 1993, tomatoes and turnip greens were sampled from nine plots located at the ORR perimeter air monitoring stations; the turnips were purchased from private gardens in nearby locations (Figure 11). Hay grown on the ORR was also sampled.

Figure 11. Individual EDEs for foodstuffs grown in the vicinity of the ORR, 1993. Although sampled in the vicinity of the ORR, about $73 \%$ of the dose from vegetables and essentially all of the dose from milk are attributable to naturally occurring isotopes or to those found in commercial fertilizers.

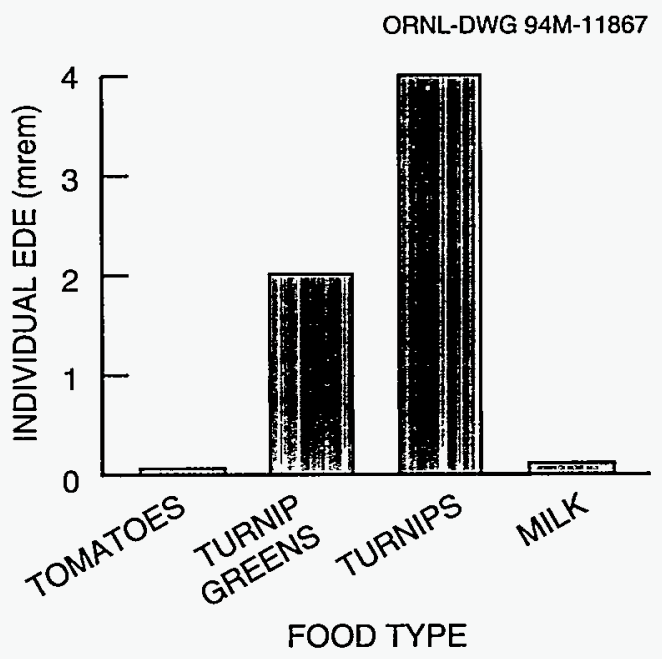




\section{White-Tailed Deer}

Several deer hunts were held on the ORR during 1993. A total of 400 deer were killed, of which 7 were confiscated because their radionuclide content exceeded the release limit. All deer were surveyed at the Tennessee Wildlife Resources Agency inspection station to determine the cesium content in tissue and total strontium in bone. The average cesium concentration in the 393 released deer was 0.27 picocuries (pCi) per gram.

The collective EDE from eating all the harvested deer meat with an average cesium concentration of $0.27 \mathrm{pCi} / \mathrm{g}$ could have been about 0.1 person-rem. The EDE for an individual consuming one deer with the average concentration of cesium was estimated to be $0.3 \mathrm{mrem}$. To estimate the EDE to the maximally exposed individual, it was assumed that one person consumed the two deer that could give the highest individual EDE because of their radionuclide content and weight. In the unlikely event that one person consumed the two deer with the highest cesium concentrations, that person could have received an EDE of about 4.6 mrem.

\section{Canada Geese}

Canada geese are known to use waters on the ORR, even though such use is actively discouraged in contaminated areas. Some data have been collected on radionuclide concentrations in these geese; however, the degree to which the collected data give a representative picture of such concentrations is unknown.

During the annual roundup of Canada geese for leg banding and collaring, whole-body gamma scans were conducted on 57 geese at the deer-checking station. Only 26 had concentrations of cesium that were considered to be statistically greater than zero. The total number of goose-hunting days in 1993 was about 70 . The daily bag limit was two geese. It was estimated that of all the geese harvested from both the Middle Tennessee Unit and Watts Bar, 426 of them could have spent time on the ORR.

A person eating the most contaminated goose could have received an EDE of about $0.01 \mathrm{mrem}$. A person eating the average goose could have received an EDE of about $0.007 \mathrm{mrem}$. The collective EDE from eating 426 geese harvested in 1993 could have been about 0.003 person-rem, assuming all were contaminated at the average level.

\section{Direct Radiation}

One of the potential exposure pathways for populations living in the ORR vicinity is external radiation. External radiation exposure rates are measured at a number of locations on and off the ORR to determine whether radioactive releases from the ORR are significantly increasing radiation levels above the normal background levels. External exposure rates from background sources in the state of Tennessee average about 6.4 microrads $(\mu \mathrm{R}) /$ hour and range from 2.9 to $11 \mu \mathrm{R} /$ hour. These exposure rates translate into annual EDE rates that average $42 \mathrm{mrem} /$ year and range from 19 to $72 \mathrm{mrem} / \mathrm{year}$. The average exposure rate at perimeter air monitoring stations around the ORR during 1993 was about $7.5 \mu \mathrm{R} /$ hour. This equals a dose rate of about $49 \mathrm{mrem} / \mathrm{year}$. Typical values for U.S. cities range from 5 to $20 \mu \mathrm{R} /$ hour, and the median for U.S. cities in 1989 (the most recent EPA data published) was $9.3 \mu \mathrm{R} /$ hour. Except for two locations, all measured exposure rates beyond the ORR boundaries are near background levels. The two exceptions are an experimental site on the bank of the Clinch River and a section of Poplar Creek that flows through the K-25 Site.

Actual fishing activity on the affected stretch of Poplar Creek needs to be determined to obtain a more realistic assessment of this exposure pathway. It is extremely unlikely that 
anyone would fish this stretch of Poplar Creek for 250 hours/year. A potential maximally exposed individual is a hypothetical fisherman who was assumed to spend 5 hours/week ( 250 hours/year) near the point of average exposure on the Clinch River. This hypothetical, maximally exposed individual could have received an EDE of about 1 mrem during 1993. This dose estimate is high because most of the source of radiation was removed in 1993.

The radiation field along Poplar Creek emanates from storage areas within the K-25 Site. The section of the creek affected by this area runs through the plant and is used at times by fishermen. EDE rates estimated in 1993 range from 0.003 to $0.006 \mathrm{mrem} / \mathrm{hour}$, with an average EDE rate of $0.004 \mathrm{mrem} /$ hour. A 4-hour fishing trip could have resulted in an EDE between 0.01 and 0.02 mrem. If the hypothetical Clinch River fisherman is used, the 250-hour/year exposure time could have resulted in reception of an EDE of about 1 mrem.

\section{Doses to Aquatic Biota}

Absorbed dose rates to native aquatic organisms (fish, crustacea, and muskrats) were calculated to demonstrate compliance with the DOE absorbed-dose-rate limit of $1 \mathrm{rad} / \mathrm{day}$. Fish and crustacea are considered to be primary aquatic organisms (those that reside in the aquatic ecosystem), whereas muskrats are considered to be secondary aquatic organisms (those that subsist on aquatic plants). Internal and external dose rates are estimated from maximum or average concentrations of radionuclides in surface waters around the ORR. With one exception, the results of these calculations indicate that the absorbed dose rates to aquatic biota are much less than $1 \mathrm{rad} / \mathrm{day}$. The one exception occurred at one point on Poplar Creek, where the maximum dose rate for crustacea was $0.73 \mathrm{rad} / \mathrm{day}$.

\section{Summary}

DOE has set a limit of no more than 100 mrem for the EDE that an individual may receive from all exposure pathways from all radionuclides released from the ORR during one year. A summary of the maximum EDEs to individuals by several pathways of exposure is given in Figure 12 and the following table. Figure 13 shows the five-year
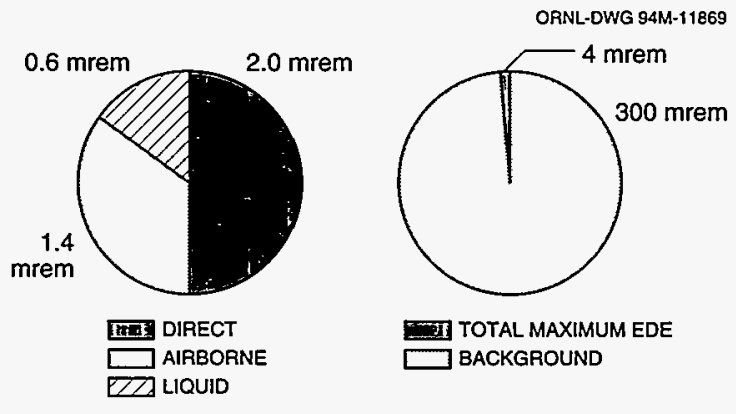

Figure 12. Summary of EDEs to an adult at locations of maximum exposure during 1993.

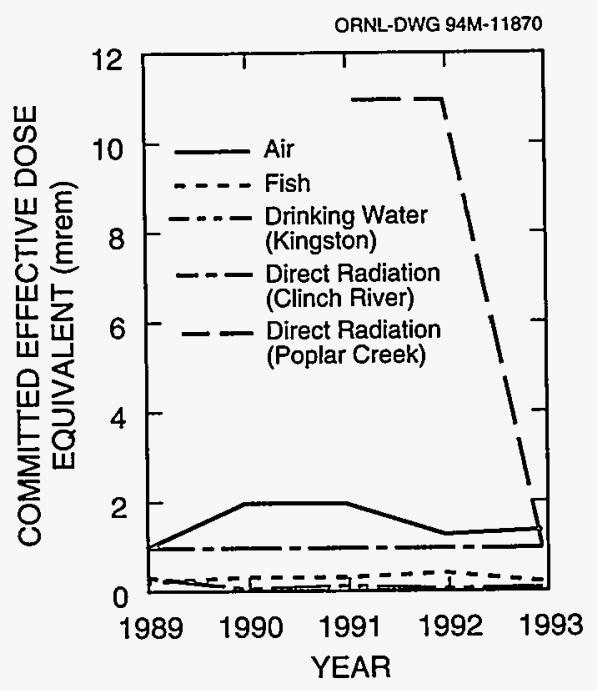

Figure 13. Five-year trends in committed EDE for selected pathways. 
Summary of estimated radiation dose equivalents to an adult during 1993 at locations of maximum exposure

\begin{tabular}{|c|c|c|c|}
\hline \multirow[t]{2}{*}{ Pathway } & \multirow[t]{2}{*}{ Location } & \multicolumn{2}{|c|}{$\begin{array}{l}\text { Effective dose } \\
\text { equivalent }\end{array}$} \\
\hline & & mrem & $\mathrm{mSv}$ \\
\hline \multirow{5}{*}{$\begin{array}{l}\text { Gaseous effluents } \\
\text { Inhalation plus direct } \\
\text { radiation from air, } \\
\text { ground, and food } \\
\text { chains }\end{array}$} & Maximally exposed resident to & & \\
\hline & Y-12 Plant & 1.3 & 0.013 \\
\hline & ORNL & 0.1 & 0.001 \\
\hline & K-25 Site & 0.1 & 0.001 \\
\hline & ORR & 1.4 & 0.014 \\
\hline \multicolumn{4}{|l|}{ Liquid effluents } \\
\hline Drinking water & Gallaher Water Plant & 0.2 & 0.002 \\
\hline Eating fish & Clinch River, CRK 32 & 0.2 & 0.016 \\
\hline Other activities & Clinch River & 0.2 & 0.002 \\
\hline \multirow[t]{2}{*}{ Direct radiation } & Clinch River shoreline & $1^{a}$ & 0.01 \\
\hline & Poplar Creek (K-25 Site) & 1 & 0.11 \\
\hline
\end{tabular}

aThis is an overestimate of the potential dose because the source of direct radiation was remediated during 1993.

trends in committed EDE for selected pathways. It is unlikely (if not impossible) that any person could have been irradiated by all of these sources and pathways for a period of one year. However, if the resident who received the highest EDE from gaseous effluents, also drank water from the Gallaher plant, ate fish from the Clinch River, and fished the Clinch River near the cesium field, he or she could have received a total EDE of about 3 mrem, or about $1 \%$ of the annual dose (300 mrem) from background radiation. If the individual fished Poplar Creek, the maximum individual dose also could have been about 3 mrem, $1 \%$ of the natural background dose.

\section{PERSPECTIVE ON RADIATION AND DOSE}

Most radiation occurs naturally, and everyone is exposed to it. Naturally occurring radiation is the largest contributor to the average individual's annual dose (Figure 14).

\section{Background Radiation}

People have no control over the amount of natural radiation around them, which stays about the same over time. In fact, the natural radiation present in the environment today is not much different than it was hundreds of years ago. Sources of natural, or background, radiation include internal radiation from food, potassium for example (everyone has approximately 500,000 atoms disintegrating in their bodies every minute); solar radiation from the sun and cosmic radiation from outside the solar system; and terrestrial radiation from the earth's rocks, soils, and minerals. Exposure to background radiation varies greatly depending on individual lifestyles, such as where a person lives and what materials were used in the building where that person lives. 


\section{Human-Made Radiation}

Sources of human-made radiation include consumer products, such as color televisions, cigarettes, camera lenses, smoke detectors, and fertilizers, and medical sources, such as $\mathrm{X}$ rays, diagnostic tests, and treatments. Human-made radioactive materials also include cesium-137 and strontium-90, which are present in the environment as a result of nuclear weapons testing that was conducted in past years. As with background radiation, exposure to human-made radiation varies greatly depending on individual choices, such as smoking and eating certain food products.

\section{Comparison of Dose Levels}

The dose received by a given individual can vary widely from year to year depending on numerous factors. The average individual in the United States receives a dose from natural exposure more than 200 times greater than he or she receives from nuclear industry operations (see the following table).

The average dose caused by background radiation also varies widely. In the United States, the average is about 300 mrem per year; however, some people in other parts of the world receive a dose more than four times this amount. For example, in some areas of Brazil the dose to inhabitants can be more than 2000 mrem per year from background

ORNL-DWG 94M-9702R

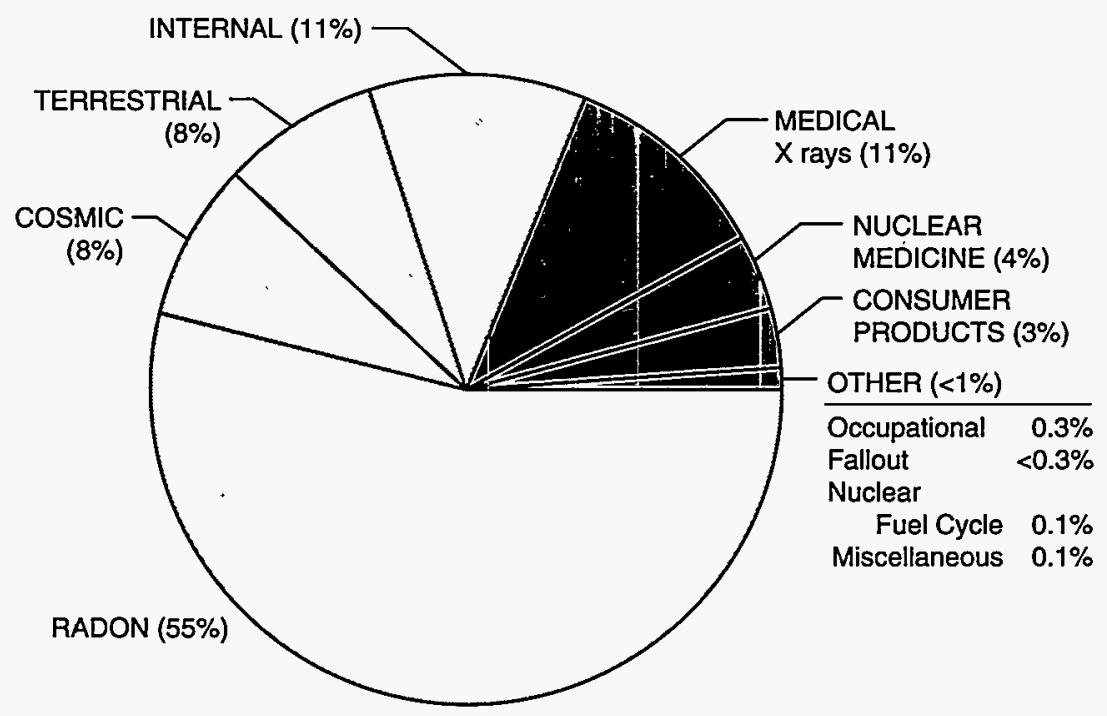

NATURAL (82\%) MAN-MADE (18\%)

Figure 14. Sources of radiation. Radiation has always been present, and every person who has ever lived has been exposed. Although modern technology seems to have greatly increased the exposure rate, this is not necessarily the case. Exposure to human-made radiation varies greatly based on a given individual's product choices and medical treatments. In fact, exposure varies more based on where a person lives than on an exposure to human-made sources. For example, the average individual in the United States receives 28 mrem per year from radioactive elements in the soil. However, the average dose from the soil in some areas of France is $350 \mathrm{mrem}$ per year. Figure redrawn, with permission, from lonizing Radiation Exposure of the Population of the United States, National Council on Radiation Protection and Measurements, 1987. 
radiation. These variations are caused by several factors, most notably the type and amount of radionuclides in the soil (Figure 15).

This diversity in background radiation, not human-made radiation, is responsible for the large differences in the dose to average individuals. Because people living in areas with high levels of background radiation do so without proven harm, it is assumed by most in the scientific community that the extremely small variations in dose caused by ORR releases have inconsequential, if any, effect on humans. (See the following table for a comparison of various dose levels.)

Average annual radiation dose in the United States

\begin{tabular}{lcc}
\hline \multicolumn{1}{c}{ Radiation type } & $\begin{array}{c}\text { Average dose } \\
\text { (mrem) }\end{array}$ \\
\hline & Natural & \\
Cosmic & & 27 \\
Internal & 239 \\
$\begin{array}{l}\text { Terrestrial } \\
\text { (mostly radon) }\end{array}$ & 28 \\
& & \\
Consumer products & Human made & \\
$\begin{array}{l}\text { Medical sources } \\
\begin{array}{l}\text { Other (includes } \\
\text { nuclear industry) }\end{array}\end{array}$ & 10 \\
\hline
\end{tabular}

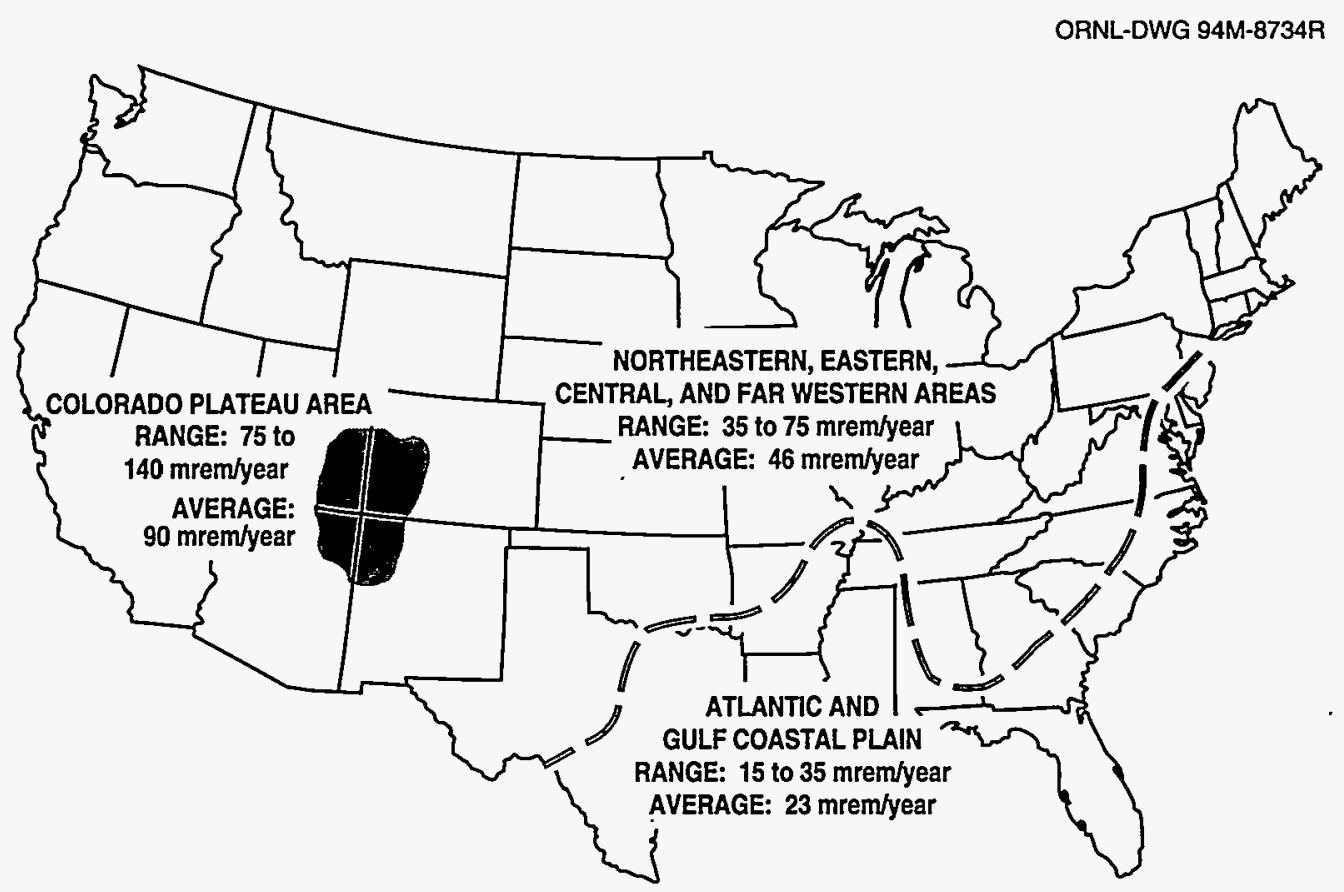

Figure 15. Average dose from terrestrial radiation in the United States. Large deposits of uranium and thorium ores in the southwest are responsible for the higher than average dose in the area known as the Colorado Plateau. Figure redrawn, with permission, from Low-Level Radiation Effects: A Fact Book, Society of Nuclear Medicine, Inc., New York, 1982. 
Comparison and description of various dose levels

\begin{tabular}{|c|c|}
\hline Dose level & Description \\
\hline $1 \mathrm{mrem}$ & Approximate daily dose from natural background radiation, including radon. \\
\hline $2.5 \mathrm{mrem}$ & Cosmic dose to a person on a one-way airplane flight from New York to Los Angeles. \\
\hline 10 mrem & $\begin{array}{l}\text { Annual exposure limit, set by the USEPA, for exposures from airborne emissions from } \\
\text { operations of nuclear fuel cycle facilities, including power plants, uranium mines, and } \\
\text { mills. }\end{array}$ \\
\hline $46 \mathrm{mrem}$ & $\begin{array}{l}\text { Estimate of the largest dose any off-site person could have received from the } \\
\text { March } 28,1979 \text {, Three Mile Island nuclear accident. }\end{array}$ \\
\hline 66 mrem & Average yearly dose to people in the United States from human-made sources. \\
\hline $100 \mathrm{mrem}$ & $\begin{array}{l}\text { Annual limit of dose from all DOE facilities to a member of the public who is not a } \\
\text { radiation worker. }\end{array}$ \\
\hline 110 mrem & Average occupational dose received by U.S. commercial radiation workers in 1980 . \\
\hline 244 mrem & Average dose from an upper gastrointestinal diagnostic $X$-ray series. \\
\hline 300 mrem & $\begin{array}{l}\text { Average yearly dose to people in the United States from all sources of natural } \\
\text { background radiation. }\end{array}$ \\
\hline 1 to $5 \mathrm{rem}$ & $\begin{array}{l}\text { Level at which USEPA Protective Action Guidelines state that public officials should } \\
\text { take emergency action when this is a probable dose to a member of the public from a } \\
\text { nuclear accident. }\end{array}$ \\
\hline 5 rem & $\begin{array}{l}\text { Annual limit for occupational exposure of radiation workers set by the U.S. Nuclear } \\
\text { Regulatory Commission and DOE. }\end{array}$ \\
\hline 10 rem & $\begin{array}{l}\text { Estimated level at which an acute radiation dose would result in a lifetime excess risk } \\
\text { of death from cancer of } 0.8 \% \text {. }\end{array}$ \\
\hline $25 \mathrm{rem}$ & $\begin{array}{l}\text { USEPA guideline for voluntary maximum dose to emergency workers for } \\
\text { non-lifesaving work during an emergency. }\end{array}$ \\
\hline 75 rem & $\begin{array}{l}\text { USEPA guideline for maximum dose to emergency workers volunteering for } \\
\text { lifesaving work. }\end{array}$ \\
\hline 50 to $600 \mathrm{rem}$ & $\begin{array}{l}\text { Level at which doses received over a short period of time will produce radiation } \\
\text { sickness in varying degrees. At the lower end of this range, people are expected to } \\
\text { recover completely, given proper medical attention. At the top of this range, most } \\
\text { people would die within } 60 \text { days. }\end{array}$ \\
\hline
\end{tabular}

Adapted from Savannah River Site Environmental Report for 1993, Summary Pamphlet, WSRC-TR-94-076, Westinghouse Savannah River Company, 1994. 